\title{
Mixing, Moving, Making, Meaning: Possible Futures for the Distant Past
}

\author{
David Schoenbrun
}

(C) Springer Science+Business Media, LLC 2012

"Thinking Across the African Past," this special issue of the African Archaeological Review, bridges disciplinary conventions between archaeology, historical linguistics, and anthropological genetics in order to transform the results of their dialog and respect their distinct epistemologies. Thinking expansively, the essays published here reinvigorate old debates and open up entirely fresh ones. Debates about the timing of settlement sequences still exist, but increasingly address cultural dimensions of how settlement was accomplished, in regional contexts. Debates about correlating streams of evidence continue, but increasingly we ask questions about the common ground of meaning that the traces made in the past and the ways in which they have been borne into the present. Debates about integrating the powerful material of anthropological genetics still largely unfold within the frame of settlement sequences, but increasingly promise unparalleled fineness of resolution, bringing into view the embodied, sexed individual in a distant past.

The way back to the long ago is at once familiar and exciting. The familiar mixing of disciplines and the exciting new emphases on process, meaning, and individuals happens through narrative strategies of exposition - in a word, stories. Stories bind the bench science, social science, and humanities around the people whose lives our work seeks to articulate. Whether the stories structure the arguments at stake or those arguments lie beneath the general narrative structure we build, all of us work through stories. Whether pushing a point or a story into the foreground, we all rely on narratives about the past, revising or confirming some parts of them as we work. In one sense, the interdisciplinary work in these articles could be conceived in terms of a shared investment in the rewards and risks of the narrative structures that live through, and are transformed by, the points of stories.

Narrative structures reveal new gaps between the disciplines we use to write about the past, calling out as the blank spots in our knowledge of the African past change shape. Only the rare author, like Basil Davidson, adopted the qualities of the narrative

D. Schoenbrun $(\bowtie)$

Northwestern University, Chicago, USA

e-mail: dls@northwestern.edu 
as an expositional strategy. Keenly aware of the empty places in his archive, Davidson nonetheless appreciated that the future of scholarly interest in Africa lay with both basic research and a lively lay audience. Large and crucial voids remain in Futa Jallon, Angola, in the vast regions between the Senegal, Middle Niger, Lake Chad, and Nile basins, the Benue River valley, and on the Adamawa Plateau, to name just a few (MacEachern 2012). Nevertheless, the densities of information about some African pasts in the Southern African Highveld, the middle Swahili Coast, the Middle Senegal, Middle Niger River, and Lake Chad Basin, central Ghana, southern Nigeria, and so forth, have reached a turning point because they support exploring qualitatively new questions about the complexities and contingencies of the lives of those who made the past, while raising questions about what we need to know next.

The rewards and cautions of narrative approaches to method, correlation, and intervention bring the part of history that lies in the humanities back into our world. After all, when we "account" for something, as Fleisher and Wynne-Jones urge us to do with regard to the materiality of place-making, we are invoking a form of narrative: subtracting, adding, and reckoning in order to tell about change, continuity, and recursive process shaping its subject. Historians take narratives very seriously, looking at them from all angles, querying their omissions (intentional or not), thinking hard about the key words they use, celebrating their quirky, surprising turns, and questing after the experiential ground of life (through the analogical work of metaphor) even as they are well aware that experience mixes alchemically with hard facts on the ground. Stories can impose clarity on complexity and they can return complexity to the seeming orderliness of existence.

The tense territory between the disciplines has long fascinated and frustrated scholars and readers, as de Luna reminds us. Important correlative and chronological concerns continue to stretch our powers of inference. Each source of evidence we use bears different traces of past worlds, a fact first explained by Sapir (1916) nearly a century ago. Lining up those differences, to impart some form of holism to the past, continues to exercise our powers of discernment and insight. Whether or not we possess the gifts of narrative synthesis Davidson enjoyed, critical disciplinary mixing unfolds concretely through our writing.

\section{Language Worlds}

Christopher Ehret's contribution, "Linguistic Archaeology," confidently binds word and thing (or action, or concept) into a single frame of empirical historical analysis. The rules governing changes in sound-experienced in the bodily practice of hearing and speaking - ground the evidence of phonology, one part of the evidence of language, in the empirical world. Once their regularity is worked out-they are, after all, called rules for a reason - they allow us to discern inherited from borrowed items. Because words connote things, actions, or concepts, Ehret argues that "to validate the reconstruction of a word back in time to an earlier era in language history necessarily traces the" word's connotation(s) "back to the society of that earlier period" (Ehret 2012). In this piece, Ehret teaches us how to track word mobility and origins, not the problem of meaning. 
Ehret presents the patterns of sound correspondence for all to see, helping us feel confident in the validity of his phonological reconstructions. But, the rules that govern what a bundle of sounds - a phonologically reconstructed word-may connote are not bound by what is possible for the mouth to produce. Experience your own language worlds and you find that many words and things go together unambiguously - "hoe," the thing used to cleave the earth and the action of so doing - while other words and concepts or actions possess many subtle, even contradictory connotations, for example "compromise" or "oversight." Word and meaning are bound by the give and take of social communication in which the connotations of some words, like "hoe," are easy to share and the connotations of other words, like "honor," are given to ambiguity. Archaeologists always seek to understand their artifacts or features with respect to their larger spatial and other contexts (Fleisher and Wynne-Jones 2012). Historical linguists must follow their lead, for context binds the two different worlds that coexist in the words "hoe" and "honor."

The common act of connoting achieved by communicating does not automatically confer durability in each and every case. The historian must bring the settings and uses of communication to light and wonder explicitly about the different communicative lives of a sign like "hoe" and a sign like "honor." The laws that bridge these worlds, expressed by the term "lexicon," are multiple. Phonological laws work beneath the radar of social struggle. "Systematic phonological validation" will distinguish inherited items from borrowed items from items displaying a chance resemblance. Yet social struggles shape some, but not all, of the connotations phonology seeks to corral. In the cases where social struggle shapes connotation, by driving semantic variability as well as by driving coherent semantic change, depicting the contexts of use must be the stern control for tracking the durability of the linguistic bond between phonology and semantics.

At this point, we normally invoke something called "ethnography" as the source of examples of "use." Despite the well-known epistemological limits to ethnographic writing, such observations are rich sources of snapshots of meaning-in-use. However, the point at issue just now is something that writing cannot control. The use of words alters the world in which they work because to communicate is to conduct social life. The force of historical influence moves in two directions, when we think of signs. Signs do not passively bear meaning - or behave as labels for meaning - in a transparent manner. Some bear such a range of meanings, even contradictory ones, that contexts of use are the only way to sort out the intention of the speaker and the reception of the hearer. ${ }^{1}$ In other words, we have encountered Wittgenstein's (2001 [1958]: 20) idea that "for a large class of cases - though not for all - in which we employ the word 'meaning' it can be defined thus: the meaning of a word is its use in the language." His clarity belies the challenges of accessing "use" in its full breadth: all uses, not one, must be plumbed. And his hedging reveals that something beyond "use" sustains meaning.

Ehret's case study focuses on the bond between */oxol- and "donkey" in Eastern Cushitic. [For those of us who do not know an Eastern Cushitic language, the lexeme "donkey" is the sign in play here.] The unambiguous referent, signified when a

\footnotetext{
${ }^{1}$ My thanks to Paul Landau, personal communication, September 4, 2007, for an exchange along these lines.
} 
speaker and a hearer bat */oxol- or "donkey" back and forth, lends confidence to tracking that bond back into the past. The interests in play in those circumstances of communication might loosen or tighten, but not break, the sinews of that bond. Wild or domesticated, we may envision the four-legged creature that */oxol- signifies, braying sullenly or bouncing along roughly, back in the day when a group of people spoke something we now call "Proto-Eastern Cushitic." Yet, even this bond depends on our having seen the animal before or having had it pointed out to us and associated with a name in the use of language. It is not hard to understand that other such pairings might slip their bonds more easily.

The fields of meaning in linguistic reconstructions do not respect their tethering to signs in the same manner. Meanings may be understood as objective, lying in part beyond the linguistic world. They may be understood, or reverse-engineered, through parsing the relations of bits of meaning within a lexicon. Or, they may be grasped as mental phenomena, wholly or partially linguistic, through metaphor (Ullman 1979: 54-67; Traugott and Dasher 2005). Ehret's example survives each of these modes of understanding "the meaning of the sign */oxol-."

But when we understand meaning as playing a role in language changing the world, it does not merely reflect the world "inside" our brains or objectively "out there." Historical linguists in Africa who attend to semantics take either an objectivist or mentalist approach, perhaps because we are forced to work almost entirely without the contemporary documented examples of usage that lexicographers mine for the shape of the field that encompasses a word's referents. We have our field elicitations, our dictionaries, and our ethnographic or "travel" literatures, collections of attestations or claims in complex semantic worlds. With these hints about a word, as Robertshaw would have it, we are left "to ponder its semantics" (Robertshaw 2012). In the absence of instances of use contemporary with the times in the past about which we write, inferences about the past rely on analogies from patterns of semantic change and continuity observed and documented more recently or by analogy to other contexts in which contemporary instances use exist. Under these circumstances, the potential for miscommunication in the present is compounded in the past we historical linguists infer.

I count myself among the scholars who point out that the number of words with overlapping fields of connotation that a historical linguist may "reconstruct" increases our confidence in understanding the ways in which connotations mutually constitute one another (Fleisch 2008). This is a version of the "parsing" approach to fixing meaning. Such bundling ponders earlier semantic fields with similar or different shapes, on the principle "that meaning arises from the set of semantic relations within the lexicon like synonymy, antonymy" or polysemy. It is "the placement of individual expressions within this system" that helps generate meaning linguistically, not extralinguistically (Bussmann 1996: 299).

The technique raises the stakes for imagining the communicative contexts through which people achieved continuity of connotation and influenced their worlds. This work of imagination is delimited by the initial conditions under which people attest (or attested) those connotations, and they or others capture(d) them in writing - most often ending up in dictionaries. For some "connotations" specific interests conditioned their capture. The great majority of such repositories, produced closest to the time of imperial conquest and/or colonial rule, were by missionaries (Peterson 1999; 
Landau 2010: 79-83). When the historical linguist works directly with speakers of a given language and not with dictionaries, she still works in a time of literacy, in the aftermaths of the mission, the colonial school, or the non-government organization (MacGaffey 2000: 43-60). Even the "hardness" of empirical reality shape-shifts beneath us, its solidities and liquidities susceptible to the binding wiles of narrative where the power of regularity, of systematicity fades in the hurly-burly of social history. Narratives resting on such evidence hop from branch to branch of empirical solidity separated by the ambiguities of communication and context. The tree diagram is among the most common representations of the empirical solidity of divergence.

Another path through semantic tangles also relies on analogy: the cognitive linguistic notion of conceptual metaphor (Lakoff and Johnson 1980; Sweetser 1990; Traugott and Dasher 2005: 75). Conceptual metaphor glosses the human brain's capacity to model complex or abstract phenomena by analogy to concrete or simpler phenomena. This process works through correspondence between a source domain and a target domain. Some conceptual metaphor, such as EMOTION IS TEMPERATURE, is widespread, perhaps universal, in daily language: "he cooled off after the heated meeting." Some conceptual metaphor is more restricted in use. When Luganda speakers say "the kabaka [king] eats the drum" they offer an instance of nested conceptual metaphors, POWER IS EATING and MONARCHIES ARE DRUMS. A royal center consumes the wealth of the land and its people (Bayart 1993; Schatzberg 2001). Assembled musicians, singers, dancers, officials, and their audiences constitute a kingdom. The correspondences between images and schemata of eating and ruling arise from experience. Mapping the controlled chaos of large public performances, one may understand more readily the multiple simultaneous activities and specializations of a kingdom. Whatever the conceptual metaphor is, one understands and communicates about the more abstract experience (of rule, of kingship) using the concrete, structured experience of eating or musical assembly as a source. Correspondences between them prompt "a conceptual projection of additional entities, properties, and relations from the more concrete source domain onto the more abstract target domains" (Ortman 2012: 204). By that means, conceptual metaphor generates new metaphors and, thus, facilitates reconfigurations of semantic fields. The experience of eating involves destruction, pleasure, waste, growth, and transformation. Each of those aspects of the source domain's experience fits onto different aspects of the experience of power. The experience of attending public dance performances involves healing, feasting, competition, judgment, reciprocity, and so forth. Each of those aspects of the source domain fits onto different aspects of the experience of royalty

The use of conceptual metaphor lies in an indistinct zone between intentionality and unreflective quotidian use. We are neither ruled by metaphor nor entirely free from its governing qualities. Laying out the details of the ways in which metaphor facilitates correspondence between source and target domains and moves from novel, intentional attempts to connect a source to a new target to unthinking use of those correspondences, lies beyond the scope of this essay (Ortman 2012: 204-25 and citations in note 2). But the basic point about source and target domains of meaning and understanding and communication goes to the heart of my argument here about the necessity of stories and historical imagination to entwine the sense we make of our various sources, separately and together. The poetic power of conceptual 
metaphor is not only "a significant component of the concepts themselves" (Ortman 2012: 205). It emerges from cognitive as well as social and cultural realities. Thus, conceptual metaphor opens a common ground of meaning between linguistic, material, and spatial worlds when archaeologies of place-making and semantic studies of language achieve fine enough resolution that we can test for conceptual metaphors providing correspondences between them.

Conceptual metaphor frames the fields in which people find and make meaning. Readers will understand what I am doing when I write that "conceptual metaphor frames the fields in which people find and make meaning" because they have assimilated the idea that MEANINGS ARE CONTAINERS ${ }^{2}$ and no container works without having walls or edges. A meaning is expressed, in part, by placing some things inside and others outside of it. I cannot hope to communicate without making distinctions and using containers provides a concrete source domain of experience for the task of communicating meaning.

As exciting and inspirational as it is, conceptual metaphor nevertheless falls short of bridging all "frames of meaning" to the ethnographically rich communicative environments in which we may assess degrees of message reception, whether resistant, ignorant, or otherwise. But, conceptual metaphor helps us think about the durability of fields of innovation in meaning, even as their shapes change as a result of the source domain recruiting, through use, senses of meaning from the target domain. Because some conceptual metaphors rely on phenomenological universals of human bodily experience and others rely on specific environmental or historical material, they are neither "universal and objective, nor radically relative and subjective" (Ortman 2012: 206) They are "metaphors we live by" (Lakoff and Johnson 1980). And, in living by using conceptual metaphors that "take," we draw to the vocabulary of the source domain senses of meaning derived from the target domain, through use. Polysemous terms, compound words, and semantic shifts in a word's referent all potentially carry traces of conceptual metaphor, making change and continuity in conceptual metaphor subject to empirical analysis.

In Luganda, a Bantu language spoken today along and inland from the northwest shores of Lake Victoria, "Obuganda" refers to the abstract idea of the collectivity of people who live in the monarchy of Buganda. It is a word made up of an initial vowel or pre-prefix /o/, a noun class prefix /bu/ and a stem /ganda/. The polysemous meaning of the stem includes "group, bundle, heap, relatives, pole, clan" (Schoenbrun 1997: 78-80). The noun class prefix applies an abstract ontological quality to the stem's referents, giving "groupness, relatedness." The initial vowel or pre-prefix fixes the abstract, ontological quality of shared belonging in a particular place. The term contains the trace of a conceptual metaphor FAMILIES ARE HEAPS, developed as a means to expand the scale of collective identification beyond a particular descent group, a group of siblings of the same sex, or a shared location in order to make sense of the diversity of individuals, living in different locations, who share a given clan identity. But it adds to that idea the idea that a monarchy is like a big group of relatives. The term contains traces of a time when people drew on their concrete experience of piles and groups of things and people to make sense of social organization of disparate peoples. But a monarchy was, in part, a collection of families,

${ }^{2}$ Lakoff and Johnson (1980) introduced the convention of depicting conceptual metaphors in capitals. 
lineages, and clans, jumbled together haphazardly, definable in part by a shared yet imaginary space. MONARCHIES ARE A FAMILY expresses a key dimension of political culture in the Kingdom of Buganda: spirited competition among clans for the throne. This conceptual metaphor does not exhaust the analogies Ganda speakers developed for thinking and talking about their kingdom. ${ }^{3}$ But it does suggest the ways in which conceptual metaphor opens a portal into Ganda-speaking minds of the past.

Conceptual metaphor is not only a linguistic process. It is expressed in other phenomena such as making things and organizing space. Scott Ortman has applied this basic insight more effectively than any other scholar to the task of integrating archaeological and linguistic evidence. He argues that conceptual metaphor is "a common denominator of material culture and language" (Ortman 2011: 111). Conceptual metaphors may be reconstructed linguistically and expressed in material or spatial form. When a conceptual metaphor draws on material culture or spatial form, it offers the best means to bridge stories of change and continuity built from archaeological and linguistic evidence. This is a rather more capacious portal between the two disciplines than Vansina's (2004) technique of "direct association" taken up so powerfully in de Luna's essay (de Luna 2012). It has the capacity to reveal the success of innovative metaphorical associations, offered up by unknown speakers of a language, makers, and users of things and space.

Conceptual metaphor allows us to bind archaeological and linguistic sequences in powerful ways when materiality and spatial form appear in source and/or target domains. That correspondence means we may reason about the earlier linguistic identity of the makers and users of suites of material culture when language shift may have obscured that relation. Conceptual metaphor also helps locate forms and modes of meaning that operate unreflectively yet are susceptible to innovation in specific times and places, distinguishing them from the kinds of meaning that rely on contextual usage for understanding. That distinction begins to unpack the contents of "meaning," [in keeping with the conceptual metaphor MEANINGS ARE CONTAINERS] a central but often unmarked category common to many of the papers in this special number.

In order to think about language, material culture, and spatial form in the single frame of conceptual metaphor, the basic evidentiary records for each field must be comparably extensive and well dated. That minimum requirement for checking correspondence among the parts of a conceptual metaphor that suffuses each field obtains in few places. Ortman worked out his powerful insights along these lines in the Upper Rio Grande Valley and the Mesa Verde Region of the US Southwest, a context of extraordinary, rarely equaled richness of evidence and chronological precision. The archaeological record of the US Southwest, between the sixth and the fifteenth centuries $\mathrm{AD}$, can only elicit envy from those of us interested in the history of Africa in the same time frame. Yet, one can still try on conceptual metaphor as a fabric of meaning weaving word, thing, and place together, where the records of each are present. To do so will add support to Ehret's insistence on the solidity of linguistic evidence.

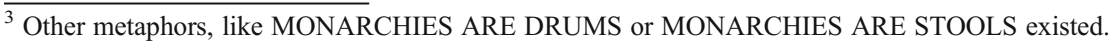


Safely at one table of empirical evidence, the criterion for communication between the different kinds of information seems obvious: it is the human-in community, as a person, in relation to other forms of life, and in relation to things and places. And, in an obvious way, the brain serves as the crossroads for the disciplines. The human brain makes and inhabits very many of the meanings that we analyze and interpret. The human, in these varied and tense relations, allows us to braid the different sources of information together, into a story. Conceptual metaphor offers the chance to build that story drawing on the meaning-making processes used by the subjects themselves. This is in keeping with Robertshaw's echo (Robertshaw 2012) of the call for deep regional work by Ann Stahl (2009) in which the materiality and semantics of cultural process emerge to bind different units of analysis - the archaeologist's site, the historical linguist's speech community, the geneticist's population - offering paths toward the historical human, to say nothing here of oral tales, histories, and traditions. Robertshaw's worry that valuing such process differs in fundamental ways from the values of pragmatic scholars based in Africa who desire utility over theory as the product of their labor (Robertshaw 2012), might be assuaged by a turn to narrative if that turn increases the accessibility of our work.

Narratives can synthesize different units of analysis and generate common ground among scholars working under different circumstances of resource constraints by evoking change, continuity, and recursion. But the type of evidence with which we work shapes the sorts of narratives we can produce. I urge us to push debates over the shapes of this challenge beyond concerns, voiced by Robertshaw (2012), with the influence of currents in academic theory that authorize us to write about systems, or evolution, or structures, or struggle, or process, even the new frame of regional culture-making process. Each of those rubrics (and others easily come to mind) is useful to us in framing a research program, carrying it out and writing it up. But the ability of narrative to line up and braid all of these rubrics is at least as important for us to debate as are the forms of temporality, relations between locales and regions, questions of meaning, power, identity, and so forth that we wring from our evidence. More than a plea for worrying about prose mechanics and style, a "return to narrative" calls for taking conceptual metaphor seriously as a common ground of meaning with which we all work and to which our research agendas aspire to explicate. It calls for us to braid together the disparate chains of inference each source yields without necessarily violating the different worlds they reflect. Narrative can push correlation and association into the background by foregrounding the detail, diversity, and complexity of places and networks. Narrative can connect the different units of analysis native to particular disciplines, by humanizing them. A return to narrative will help us bring to life the worlds of communication, mobility, spatial form, environment, and bodily exchanges that produced the "hard evidence" that we generate, analyze, and interpret. Narrative makes points just as easily as it tells a story.

\section{Gene Worlds}

Genetic evidence is technically complex. Now I know how some must feel when they read the parts of my work that rest on historical linguistics. As McIntosh and 
Scheinfeldt (2012) explain, genetic evidence brings the shape of genomic genealogies, haplogroups ("lineages"), and a certain kind of demographic history into the conversation about correlation. It can help us distinguish population movement from the movement of artifacts or ideas or languages. When combined with stable isotope analyses, it comes with a powerful new promise of detailed recovery of virtually everyone's place in a tapestry of lines of descent and sex and movement. Genetic evidence for nonrecombining and autosomal inheritance will bolster even further what Robertshaw (2012) calls our "hard won culture-historical sequences" by adding significant statistical heft to sequences and patterns of demic and cultural diffusion.

It will do so for two precise dimensions of those sequences. Genetic evidence tells us clearly that people moved around and had sex. Those are two historical facts that put punch and life into the stories that constitute culture-historical sequences. McIntosh and Scheinfeldt (2012) weigh in on the story of the braiding of sources of people who settled the Pacific islands and the broad swathe of drier lands between the Middle Senegal River and Adamawa, in northern Cameroon. They carefully parse the available anthropological genetics to discriminate between competing narratives of settlement, while keeping open questions about circuits of movement and relay trade. In the Saharan setting of the last millennium BCE, the available archaeological evidence reveals a network of pastoral transhumance and contact exchange binding herders and smiths from the Middle Senegal River valley, the copper mines at Akjoujt, and Punic North Africa. With the skeleton of a region of trade, subsistence, and gene flow sketched in, McIntosh and Scheinfeldt (2012) articulate research questions for further discrimination of population histories. Their essay shows just how forcefully - if still too bluntly-genetic evidence pushes against archaeology, paleoecology, and historical linguistics.

Yet, the indeterminacies of their narrative of population history reveal the new blind spots in our information. Settlement histories inferred from historical linguistics have reached a critical mass of example and nuance (Ehret 2002). Regional studies by archaeologists, sometimes taking historical linguistics into consideration (Mitchell 2002; Reid 2003; Ogundiran 2005; Lane et al. 2007; Ashley 2010; Fleisher and Wynne-Jones 2010), and other times leaving them aside (McIntosh 1998, 2005), likewise have attained new levels of resolution. But the promise of anthropological genetic evidence, produced over the last two decades, is limited by inconsistent collection protocols and differential degrees of resolution. Although today, anthropological genetic evidence lags the two other disciplines, even with respect to resolving issues of timing and location for settlement histories, McIntosh and Scheinfeldt make clear that will not be the case for long. Increasing the resolution of identification and genotyping of the LP alleles that mark lactase persistence in Maghrebian, Saharan, and Sahelian populations will add detail to the history of milking in the region. While we await better testing for ancient DNA from populations in these regions, linguists might focus their comparative method on reconstructing taxonomies of terms for types of milk and its conservation, the labor of milking, the various containers used in collecting and processing milk, and breeding taxonomies for livestock that define milk-producing animals. Set against the historical classifications of Berber, Atlantic, Chadic, and other intermediate subgroups of Niger-Congo, Nilo-Saharan, and Afro-Asiatic relevant to this region, such taxonomies offer an alternative stream of evidence we can directly associate with the 
archaeological record. In addition to the helpful suggestion of Blench (personal communication with S. K. McIntosh) to focus on identifying patterns of linguistic transfer of terms related to herding and milking, formal lexico-semantic reconstructions of terms for containers, breeding animals, and conceptual metaphors surrounding milking and herding offer additional possibilities for direct connections between archaeology, anthropological genetics, and linguistics.

Genetic data promise us the body, but it too often comes draped in sociological and anthropological categories like marriage or gender. Genetic evidence is much poorer in telling the human stories - with all their indeterminacies and cognitive dissonance - that explain that movement and frame that sex. To insist on an apparently minimalist notion of "sex," free from sociological entanglements, avoids the difficult challenges of depicting historically contextualized meaning. But how should we narrate histories of the coupling that produced that evidence? Surely we cannot write about marriage based on such evidence. And, yet, "gene flow" sounds a little too clinical. Perhaps when the embodied individual life in motion takes clearer shape, from other sources, we can place her or him in a social and physical setting.

More importantly for lay and scholarly use of anthropological genetics, McIntosh and Scheinfeldt's essay reminds us that people do not reproduce in gene pools somehow defined by whatever language they speak. The widespread reality of multilingualism, today and in the past, reflects the contingent character of the isomorphism between gene pool and language. The "complexity of human behavior" they point to in issuing this warning includes the ability for one embodied person to belong to more than one speech community. Even if she herself belongs to only one gene pool - as the product of her parents' mixing two gene pools to produce her-she may generate offspring belonging to still other mixtures. So, historical linguistics and anthropological genetics may join together in narratives of the transgenerational continuities and change in knowledge and coupling. Even though we sample individual bodies and speech, we place the contents of that sampling into the flow of time, the extensions of space, and the mingling of bodies. The technical complexities and virtuosity of method in genetic history should not distract us, as it has in historical linguistics, from addressing the bigger problem of the limitations of interpretive insight we can gain from it.

Whatever the limitations are (discussed above), they must not muddle the precision with which anthropological genetic and historical linguistic evidence sorts out cladograms of lineage divergences. Anthropological genetics provide powerful tools for sequencing or stratifying the formation of distinct lineages, reasoning about the timing of the steps in the sequence, the number of people involved, and the sex of contributing innovators. McIntosh and Scheinfeldt's mutations, constitutive of haplogroups, produce the same analytical results as Ehret's sound changes. Not surprisingly, perhaps, their application of the available evidence along these lines sets aside the two simplest academic stories about settling Oceania: everyone came from Southeast Asia very recently or everyone came from Melanesia very recently. It was messier than that.

Yet, they are not the same sort of evidence as that of language, material culture, or spatial orders. Precisely because genetic evidence still leaves so much to the imagination with respect to Robertshaw's (2012) cultural process, it cannot easily resist someone projecting today's thinking about identity, sexuality, and mobility onto a 
narrative of population divergences. The social and cultural blind spots in that narrative - and the narrative's combination of breathtaking scope and intimacyallow both lay audiences and academics to find themselves in the story. A beguiling prospect that any storyteller desires to foster, the inability of this evidence to provide answers to processual questions creates an interpretive vacuum where anachronism and retrograde ideas binding genes and language too often enter (Robertshaw 2012). That should influence the terms on which "mainstream" historians take up the historical narratives we produce from genetic evidence. In short, can we look behind genetic history for historical context? Or does genetic history lead along its own pathways to similar vistas on settlement chronologies gained from linguistic, archaeological, and paleoecological evidence?

It seems to me that genetic evidence raises its own questions. It does not just help historical linguists and archaeologists date and track the movements of their people. It raises questions about the social history of power that surrounded the sex and mobility it tracks. Where it is possible - in the Middle Senegal Valley? in the Lake Chad Basin? to model language shift and multilingualism together with material and spatial histories in order to recover the aspirational settings and hierarchies under which that sex occurred, we will bring those other sources to bear on understanding the traces of social history, as well as demographic history, that come to us in genetic evidence.

Robertshaw's call for the recovery of archaic DNA that promises to join genetic lineages more closely with linguistic identifications will reveal important facts about the diversities of particular regions rich in other sources. Heat and humidity will severely constrain recovery in many parts of Africa, as McIntosh and Scheinfeldt point out, but many other parts of Africa are less affected by those conditions. Circumspection about the prospects certainly is in order. Yet, ancient DNA, where it is available, will help us see more clearly the genetic signatures of the bodies we know from other sources were here and there in West Africa north of the forests, along the coasts, and so forth. It will tell us about the patterns of movement of those bodies through particular urban settings and around particular circuits of exchange and transhumance. Down the stream of time, archaic DNA will allow us to depict the ways in which these patterns of movement changed as towns, regions, and networks rose and fell. Provocatively, it will tell us which individuals found a resting place for their expended bodies, in town or country. Such use of genetic evidence offers both an additional chain of inference about sequences and timings of movement and a prompt for more complicated questions about the contexts, meanings, and powers that shaped movement and sex there. For these reasons, archaic DNA raises particularly thorny ethical questions about the ownership of an intimate past. They are not fundamentally different from the ethical questions that attend narratives about that past.

But, what is the ethnographic analogy for genetic patterns when we have struggled so long to separate the cold facts of genetic heritage from the hot contests over historical contingency and fate? The phenomena of racial, or ethnic, or nationalist thought do not persist passively. They require continual remaking, as my colleague Jonathon Glassman (2007: 3-64) has recently explained in painful detail for modern Zanzibar and Pemba. What is the mechanism of such persistence carried to us in the demic iterations of genetic markers, if not sex itself? One rich way to address the burdens of narrative would be to recover the social histories that framed renewals of groupness through the medium of sex. 


\section{Bounding Beyond Settlement Histories: Correlating Things, Words, and Genes}

The historical linguist's concept of the "speech community" can hide the complexities of specialized knowledge distributed unevenly within it. The persistence of a speech community is proved by the continued vitality of its descendants. But people may belong to more than one speech community. Similar caveats apply to material cultural traditions. But, as McIntosh and Scheinfeldt (2012) explain, biological traditions unfold along much simpler lines of variation in which individuals do not influence the contents of the genetic material in question. It should be unsurprising when the three streams of evidence do not align across time and space and it should be cause for explanation when they do line up.

MacEachern's piece points out the value of dissonance in the findings from different sources concerning the subsistence economies and the timing of early settlement in the Lake Chad Basin. Lexical evidence says those settlers grew grains. But the earliest archaeological evidence for grains is not older than 1200 BC (MacEachern 2012). MacEachern resolves the contradiction by pushing the underlying "interactions" among Chadic and Nilo-Saharans, that some linguists argue drove settlement in the Lake Chad Basin, somewhere to the north and suggesting that "other cultural trajectories" governed Lake Chad Basin settlements. He is surely right.

However, what if the knowledge of grains adduced for Proto-Chadic by historical linguists, was itself a specialized knowledge possessed by some but not all ProtoChadic speakers? The reconstruction of starred forms rests on a stable transmission of the lexemes from the distant past into the moment when they enter the documentary record. Starred forms do not tell us about the distribution of the knowledge they signify among all communicative networks of, in this example, Proto-Chadic speakers. The dissonance in MacEachern's case study invites us to rethink the uniformity of semantic worlds in the past.

de Luna raises similar questions, but answers them differently. She reads the variability of hunting signatures in the archaeological record for the Kafue Basin, in the three centuries prior to $1000 \mathrm{CE}$, in the light of her classification of Botatwe languages and the creation of new hunting knowledge by two of its descendant branches whose speakers lived in the same territories that are today home to the archaeological sites. She finds close fits between specialized spearcraft at Kalala Island in the Kafue Basin and the vocabularies for spearcraft in Proto Central Eastern Botatwe (PCEB), one of the second-order subgroups that emerged from Proto-Botatwe. Fits between the dating of Chadic speakers' grain practices and the archaeology of cereal agriculture do not work. But fits between the dating of PCEB spearcraft, and the archaeology of specialized hunting, work well.

de Luna interprets the "wasteful butchery practices" reflected in "specific portions of the carcass" (de Luna 2012) turning up, rather than the entire animal, as evidence of increased killing efficiencies, sport, or trade. But these data might also reflect the orderly distribution of parts of the animal among different members of the hunting party who lived in different locations. Toward the close of the first millennium CE in the Kafue Basin, had the old integrative political practice of hunting begun tying entirely different settlements together? Should de Luna find in Kafue languages conceptual metaphors involving hunting in some fashion, she will have added even 
more depth to the direct associations binding archaeology and historical linguistics in that region.

Imagining different semantic worlds-like those shared by hunters-alive within a nominally singular speech community-like the one networked villages created-opens up new possibilities for narrating distinctive historical experiences and aspirations within and between groups constituted by bundles of unique traits. It took several millennia for the disparate material signatures of Proto-Chadic communities, some of which grew grains (not archaeologically attested) and some of which intensively collected wild grasses and fished and hunted (archaeologically attested at Dufuna and Konduga), adduced from language evidence, to join the expansive regional body of material culture, growth in site sizes and densities of occupation, that included the Lake Chad Basin, attested after 1000 BCE.

MacEachern reminds us about the chronological discontinuities between, on the one hand, the physically constrained, more precise radiocarbon dating applied to archaeological settings and, on the other hand, the inferential moves from linguistics and biology to speech community and population. These represent one of the manifestations of the epistemological differences among the primary data used by archaeologists, historical linguists, and anthropological geneticists. Chronological disparities will not go away, despite ever more rigorous attempts to correlate them. So, in addition to pursuing those efforts, we should search their discontinuities for the silver lining of differing scales of historical change and differing units of historical agency. Tightening chronological correlations when mixing methods, by generating more evidence and being aware of "assumptions and innovations in chronological reconstructions" (MacEachern 2012), we should seek narrative strategies that accommodate the irreducible differences among them. Write about cultural process set in archaeological locales. Put people in motion within linguistic and genetic interaction regions. Keep embodied humanity and humanized environments at the center of those stories.

Koen Bostoen and Birgitta Packendorf, who prepared a paper for the Conference, have shown the ways in which genetic history can set aside old chestnuts in our modeling the past (Bostoen and Packendorf 2011). Their work pushes beyond the idea that clicks could have been incorporated into Bantu languages in the course of a vaguely imagined "culture contact" to insist that we imagine more robust and sustained contact, through "intermarriage" of click using women in large enough numbers and over long enough time to "give clicks a chance." But, do the genetic histories they tell reflect intensity and duration of that "contact"? Do credible ethnographic analogies exist for us to think about differences between biological and social motherhood and use them to narrate a circumstance in which a woman from a foraging community produced a child or two "for" an agropastoral community? Historians have begun to unpack categories like "motherhood" and "marriage" in Africa's past (MacGaffey 2005; Stephens 2009). We need to engage their work as part of testing the assumptions that patterns of genetic variation in the present contain information that relates to the past, in the absence of a baseline variation map for ancestral populations, as McIntosh and Scheinfeldt cautioned. It would be helpful, along those lines, to have a sense of how much sex it takes to leave a signature. 
de Luna's paper tackles the familiar challenges of relating chains of historical inference about change and continuity in language and material culture or materially patterned expressions of social life represented by historical linguistic and archaeological evidence. Many others here have touched on the same matters (Blench 2012; Ehret 2012; MacEachern 2012; McIntosh and Scheinfeldt 2012). But de Luna pushes at the underlying assumptions guiding these efforts when she notes (p. 14) that the

relationship between pottery decoration and social identity, usually discussed as an ethnolinguistic identity by archaeologists who have assessed the region's ceramic record, serves as the foundational assumption on which one-to-one correlations between the archaeological and linguistic records have been made in south central Africa and much of the rest of the continent.

McIntosh and Scheinfeldt and MacEachern have shown us circumstances in which this assumption is and is not true. de Luna joins them by arguing that long-term continuities in decorative motifs often span a period of multiple and repeated linguistic divergences, thus upsetting a clear isomorphism between the two narratives.

de Luna then pushes into finding direct connections between the archaeological and historical linguistic records from the region. Following Vansina (2004), she proposes to reconstruct lexis for items that exist in the archaeological record with good stratigraphic provenance and careful dating. She feels that establishing a dense set of such direct links will increase the level of confidence with which we return to linking pottery traditions with speech community continuity and divergence. It is an important move - especially because it opens the way to joining the famously fraught calendar dates generated by glottochronology to the better-calibrated archaeological radiocarbon dating sequences. It increases the density of useful regional information from which narratives find their vitality.

The full promise of de Luna's move awaits a proper social history of pottery along the lines suggested by Robertshaw, McIntosh and Scheinfeldt, and MacEachern, in order to explore the assumption that the suite of material culture unearthed by archaeologists reflects the tissues and sinews of the groupness we want to find there, rather than reflecting a spatiotemporal juxtapositioning empty of a priori meaning (Gengenbach 2010, paragraphs 372-463). The "ethnolinguistic" that we set out after, using, pots and speech communities, still needs theorizing in its own terms. One way to do so would be to uncover and analyze any conceptual metaphors in language that use pottery as a source domain (David et al. 1988). Assuming such metaphors exist or existed, their structure would raise finer-grained questions about the semantic work Botatwe speakers, and their descendant speech communities, did with something as ubiquitous as pottery. At the same time, such metaphors would bind pottery and language together around the pragmatics of communicating meaning and accruing new knowledge. de Luna might look into the etymologies of names for vessel types as a starting point.

Along the way in exploring her evidence for these direct links between word and thing, de Luna (2012) evokes fleeting scenes of sociality - collective hunting of newly renamed antelope, near large rivers, or stalking pursuit of warthog in opener grassland, or setting traps at the edges of newly opened fields in gallery forest, where hungry bush pigs roamed, and especially enticing, the images of animals rushing ahead of lines of bush-beating support and into obstacles of one sort or another, near 
which skilled spear hunters lay in ambush, ready to strike their terrified prey. These moves help readers project onto the scenes a sense of the people and their relations with nonhuman beings, in motion, bringing their world to life in the course of living themselves. Though de Luna tells the story, she tells it from pieces of meaning generated in the communicative needs and experience of her subjects. It is the sort of fleshy story into which a reader can sink her teeth.

Fleisher and Wynne-Jones offer us a way to bind the inferential practices of deriving meaning from language evidence with similar processes applied to open and bounded space. By focusing their attention on "depositional acts" in particular contexts, in order to perceive "the daily activities of people, interacting with others... as they engage with material culture" (Fleisher and Wynne-Jones 2012) they shift the disciplinary burdens of making meaning from the historical linguists' language games to the material domains of place-making. With a sense of these acts, they turn to a selection of reconstructed words and their glosses, generated by the linguists Derek Nurse and Thomas Hinnebusch (1993), to think about places and words in the same frame of analysis. With this simple move, they draw the two disciplines together in new ways. The embodied atmospherics of meaning Fleisher and Wynne-Jones generate by recovering depositional practice depart from the signifying practices of words, widening our sensibilities for meaning in the past. They are the grammar, the sentence, the utterance that historical linguistics can never "reconstruct." The practice in making places of commemoration, storage, and enclaving were instances of action. Nurse and Hinnebusch's reconstructions - though they may be expanded beyond the fields sampled by Fleisher and Wynne-Jones - tend to be treated as atomistic inferences leaving us with a granular feeling of past meaning.

Both material practices and speech practices rely on context to accomplish the work of meaning - in the past and in our narratives about the past. Use was and is a large part of the common ground between them. So, the challenges of knowing the uses of spaces independent of some later descriptive instance or free from the inferential logics we apply to those descriptions in order to move into the past remain the same as the challenges of knowing the uses of words subject to the same limitations of contemporaneous description. If a scholar discovers conceptual metaphors in which spatial order is embedded - and it should be fairly easy to determine if they exist(ed), given the advanced state of Swahili and Sabaki language studies and the growing complexity of East African coastal archaeology - the metaphor(s) will form the common ground shared by archaeological and historical linguistic studies of spatial form and meaning. When Fleisher and Wynne-Jones write about "resonance" between historical linguistic and archaeological data about spatial practice, they use a conceptual metaphor (ARGUMENTS ARE CONVERSATIONS) that is familiar to all of us in order to make the claim. But we need to discover the conceptual metaphors (and submetaphors) ${ }^{4}$ at work in both Swahili language worlds and coastal urban spatial worlds. They will reveal the particular analogies with which Sabaki and Swahili speakers worked, generally and as specialists, that gave life to the link between social structure and urban form by Horton (1994), Donley-Reid (1982, 1990), and El-Zein (1974). The conceptual metaphors in question may manifest in

\footnotetext{
${ }^{4}$ Perhaps the following concatenation: [TOWNS ARE ORGANISMS (HOUSES ARE PERSONS $\{$ STONE HOUSES ARE MULTIPLE GENERATIONS < TOMBS ARE ANCESTORS $>$ \})]?
} 
a particular, exemplary form along different parts of the coast, elsewhere in the Indian Ocean world, and elsewhere on the abutting continents, expressing the family resemblances between them. With those connections between bodies of evidence established, the metanarrative that draws the bridge across the absences of use, and carries us into the past, will rest on a single foundation of cognitive conceptual understanding in the minds of the people whose speech and labor is in question.

Language, materiality, spatial orders, environment, and human biology each change and persist in different ways. Their histories should be studied, analyzed, and critiqued with respect for those differences. Yet, by agreeing to focus on the human we accept the challenge of finding the common ground touched by each one. Meeting that challenge requires conceptual innovation and narrative inspiration. The essays in this issue achieve both goals.

\section{Pleas for the Future}

The matter of literary torque turns on more than metaphor, meter, and cadence. What we choose to pursue in our disciplinary ways - whether we do so together, in conversation with one another, or all alone-might be conceptualized even more creatively than we have managed so far. Power, groupness, the affective qualities of space, the authority of science, migration, these are all rich themes. But if we approach them as objects that are already there, waiting to be discovered by our powerful methods, we lose the opportunity to bring the historical imagination to the task of narration. That imagination must not be shunned as something that weakens a claim to the truth, because imagination is precisely what people use when they try to think their way out of the known, the conventional, the prosaic. Stirring historical imagination into our fare of methods will make people want to return for more.

Historical imagination fills in around what is known empirically; it works out from there to join other islands of knowledge. But islands of knowledge expand, their boundaries with historical imagination shift. Those shifts change the textures and quality of historical imagination, too. Roland Oliver (1966: 367) imagined the initial stages of Bantu expansions as a "burst through the forest barrier" working as he did in the mid-1960s, from a set of far-flung islands of empirical knowledge about central African archaeology and the historical classification of Bantu languages. Today, our historical imagination on this topic fastens on local or regional social dynamics. We imagine firstcomers giving up their unknown language in exchange for Bantu languages (Klieman 2003), or ancient Bantu-speaking members of clans, whose names have disappeared, binding villages dispersed like beads on a string in river basins, in unnamed times of threat (Vansina 1990). The shapes and contents of accumulated empirical knowledge reconfigure the historical imagination we nonetheless rely on to draw together the edges of that knowledge and bring to life the stories of expanding Bantu languages.

This geographic metaphor underscores the ways in which historical imagination is not fiction. Fiction needs to be plausible in order to meet its consumers where they are. Historical imagination need not necessarily be plausible but it must be intelligible. It must bridge the islands of knowledge about the world of the people who made what is now known to what we readers know to be true about existing in the world: 
the full interplay of materiality and subjectivity. The island of knowledge might be another country altogether, as historians tell us we must conceive of past worlds. Our knowledge of the past is always a scarcer resource than we might like. But historical imagination and narrative can bring that scarcity and strangeness closer by respecting phenomenological distance.

Some new knowledge potentially transforms the quality of feeling that historical imagination generates, tilting it more firmly towards the historical and away from the imaginary. Ancient genetic material and stable isotope analysis offer the possibility of just that sort of change because they offer the chance to write historically about embodied individuals moving through time and space. This has been something utterly unavailable to we who imagine our way back into the life worlds of Jennejeno, Feti, Kilwa, Proto-Western Mande, Proto-Njila, Proto-Swahili, and so forth. Such genetic and biochemical evidence still requires imagination to fill in the historical heft of the social contexts that gendered, aged, classed, valued, and marginalized such an embodied individual. But it is a far different thing to write about that, when the single body in question is documented in time and space, than it is to conjure such a figure of projection from the thin air of a reader's own individuality. So, the tensions between the two terms in the phrase "historical imagination" rely on each other for existence. They produce a moving target of solidity as the ground each grows from shifts. It could hardly be otherwise. That is the reason to resist focusing on only one of them at a time. Doing so risks misrecognizing the ways in which our work depends on their mutual relationship.

The alternative is to continue to take advantage of a particular linearity to timeand a powerful spatial sweep - that puts our stories - however they are preparedbefore and encompassing of most of the stories told by the majority of historians. That fact forces many historians to look to us for ways in which they might begin lecture courses, textbooks, or introductions to their monographs. We have an opportunity to reward their hunger for beginnings with stories like de Luna's that rely on people and their fellow non-human beings as the protagonists. If we rise to that challenge, we may find favor with a wider audience feeding our historical imaginations in return.

We have many reasons to take mainstream historians' sensibilities - including the sensibility of imagination - seriously. They will help us keep the life of our stories in sight and not let it slip behind method, data, models, and sociological or anthropological concepts. Perhaps the easiest way to take them seriously means thinking hard about the metaphors by which we smuggle life into what we write.

In that regard, Fleisher and Wynne-Jones's spatial approach asks if and how social structure is reflected in town plans. They help us hedge the central role of powerful people as negotiators and actors in shaping town plans in the image of social structure by putting domestic space in play. They put the matter of space before us in a manner that leaves open the possibility that the very social structure in question takes spatial form as a result of struggles over it by parties with different interests. Spatial form does not only promote a particular experience by people, it embodies propositions about collective moralities. Their discovery at Songo Mnara (Fleisher and Wynne-Jones 2012), that the ndani (the innermost, back room of a house) was where cooking and food processing went on is entirely consistent with a newly dense urban arena in which some markers of wealth and security-such as food stuffs or the labor that went into 
producing food - might be routinely hidden until their holders deemed public display was warranted and appropriate.

If all who lived in these towns agreed on the personality of power (in the form, say, of consumerist competitions for citizenships, as my colleagues, Jeremy Prestholdt (2004) and Jonathon Glassman (1995: 165-74) have written about for the nineteenth-century "Swahili" coast), their struggles over it unfolded within a hierarchy of power. But those struggles also amounted to contests over who might occupy which parts of that hierarchy. And they were struggles beset by risks of debt that exposed the extravagant to their creditors, creating openings for the nouveau riche (Smail 2012). ${ }^{5}$

Fleisher and Wynne-Jones (2012) tell us that we need to apply ourselves to evidence about "empty" or "open" space as much as to domesticated or built space. This move offers us a chance to think about the ways in which movement formed a medium for making key categories that shape "Swahili studies:" to Islamic habitus, festive ritual, consumerist displays and tournaments of value, with winners belonging as often to inland worlds as to worlds across the seas. And to both.

But, the relations between promoting particular experiences and embodying collective moralities of power turn on the materiality of spatial form. What is used for building as much as what is built intertwine to produce experience and gloss it with the moral weight of social hierarchy that helped the Indian Ocean-African Continental borderlands of Swahili culture buzz with a famous cosmopolitanism. Did building in stone foster a new emotional disposition, an "imaginative communion with the significance of the material itself" (Stokes 1978 [1951], cited in Connerton 2011: 151)? Did the religious adornments, commodity displays, and bodily orientations of the inner rooms of such buildings compensate in some fashion for the challenges of cultural empathy entailed by cosmopolitanism (Connerton 2011: 151-3)? Fleisher and Wynne-Jones write about "domestic space" in important ways that might illuminate such questions and put the history of emotion, bodily orientation, and innovations in spatial form into conversation with historical narratives of the same topics with roots in South Asia, Arabia, and the parts of East Africa lying west of the Indian Ocean coast. That way, exploring the weight and significance of the intimacies of the local experience there may be conceptualized as, in part, managing cultural flows from these different sources and, as a result, creating a new center from which ideologies and practices of spatial form might travel.

The point to make about competitive feasting — and social memory — must include struggles over who gets to behave generously, as well as struggles over what counts in such behavior. If we think about the items (food, dress, adornment) and the behaviors (dancing, singing, music, speech) required for such work, then the beggar is just as important a figure as the Sultan, in the well-known story reported by Ibn Battuta in his Risla about the Sultan of Kilwa being dunned for his clothes, in the town's streets, retreating to the mosque to change, and giving his finery to the importunate subaltern newcomer. As Fleisher has explained elsewhere, the story is often told in part to explain the Sultan's name Abu al-Mawahib-"The Gift-Giver"-

\footnotetext{
${ }^{5}$ Smail develops an argument about the ways in which the regulation of debt, through the application of shame and humiliation by courts, nourished the growth of an apparatus of coercion in late medieval Mediterranean Europe, very much coeval, if not directly in touch with the settings here under discussion.
} 
and as an example of public display of paternalist generosity befitting an elite figure (Fleisher 2010: 201-2). But that is only one side of the story.

Where is the poor newcomer going off to with the Sultan's old clothes? Is he, perhaps intending to use them as new clothes of his own, to force his way up in a local chama? The story tells us about the difficulties elites had in keeping their luxuries elite ones, in a prestige-goods economy (Friedman and Rowlands 1978; Robertshaw 2003). But it clearly shows that subalterns desired those goods just as strongly, breaking down the barriers between reflections and constitutions of authority on one stroke (Fleisher and Wynne-Jones 2010: 180-3, 186-7). The keys to grasping the shifting terms of struggle over control of festive ritual, lie in understanding routes and modes of access to a changing or unchanging suite of items and behavior central to festive ritual. This, it seems, is just what Abu al-Mawahib found it so difficult to control; it is why ambitious newcomers to the urban scene at Kilwa or Songo Mnara or Mtwapa, et cetera, could use their own offers of clientage to wedge open the game and try to turn the tables.

It should be unsurprising, then, to learn of the enormous variety of forms the effects of those struggles took in terms of patterns of urban life. That variety reflects the combination of different continental African trajectories of desire, aspiration, and political organization, their articulation with hard facts of shifting commercial geographies and financial institutions of merchant life, the pulses of political jockeying emanating from across land, sea, and up and down the coast, and the vagaries of forces-like climate change-working in patterns whose shapes escape the actors caught up by them.

I have been asking us to think hard about translation from the products of method to the frame of meaning of the people whose traces we apply our method in order to write about them. As clearly as speaking or giving well appears to mark off difference, creating highs, middles, and lows, we should recall that speaking often shades into other elocutionary acts like singing or into activating the latent capacities of material objects such as medicines or is prompted and guided by material objects such as, in central Africa, minkisi or lukasa, to name only a few (Roberts and Roberts 1996; MacGaffey 2000). So, speaking well, in de Luna's essay, was likely very often part of a suite of performative, communicative attempts to manage situation and circumstance to particular ends. The independence with which language's meaning changes and with which material culture changes should neither surprise us nor disconcert us. It is a wonderful fact that opens into the very indeterminacies of translation. With that indeterminacy, we draw near to the stuff mainstream historians find captivating because it makes for a good story.

But McIntosh and Scheinfeldt (2012) are on to something that offers us at least one way to perceive the constant renewals so central to ethnic thought but so elusively marked in much of our evidence: the persistence of these robust borders betrays a consistent commitment to their maintenance that raises questions about the shifting contexts shaping that commitment (see also Anthony 2007). Of course, their examples come with the rich but silent detail of West Africa's historiographies echoing in the background of their settings - Takrur, "Ancient" Ghana, Mali, and so forth. We too often lack equally complex historiographies for the same time periods in other part of Africa south of the Sahara. The required historiographies must emerge from the local and regional studies that mark archaeological and some historical linguistic 
work. We need historiographically rich regions for our siblings in anthropological genetics to engage with the promise mutual ennobling in print and in various public spheres (Feierman 2006).

One way to do that might be to push toward a phenomenological approach to narrating these pasts, in order to meet Robertshaw's call for new approaches to old taxonomic boxes. Questions of meaning unfold in the phenomenological medium and push on our old metaphors, asking: What about the stories with which we weave ourselves together with beings of all sorts? How do we find the stories in organic metaphors of tree and wave and pie chart? Meaning-like ethnic thought_persists through continual renewal. Genetic material does not make life, it makes life possible: we realize its potential and introduce change in it in part by actually living our lives.

It may be easier to track and envision the constant remaking anew with meanings linked to material form and movement - such as pottery manufacture and use. But it is decidedly a different matter when it comes to abstractions like groupness, moral habits of thought, ideas and practices related to engaging disembodied forces, and the like. The quantifiability of spatial use and depositional acts, referred to in Fleisher and WynneJones' paper and in McIntosh and Scheinfelt's presentation, offers a chance to push through to "experience"-although I see no reason to oppose the two as if we had to choose between them. After all, what Fleisher and Wynne-Jones quantify are the media of experience. Experience lent and lends those media parts of the meaning we all seek.

Most who publish in this Review write about times and places without or long before writing. We write about a nonliterate past in a present full of writing. Addressing the chasm of experience that separates those two realities must be done frankly and with vivacious metaphors as bridges to that great unknowable-but imaginable - reality of life without texts.

Tim Ingold helps us: "life is lived along paths, and not just in places." One has to come and go in order to distinguish between places. Comings and goings make lines, they leave traces. "It is along paths, too, that people grow into a knowledge about the world around them, and describe the world in the stories they tell" (Ingold 2007: 2). We can say rather more about such movements. Virtually all of the papers are virtuoso performances in retracing steps: the steps of potters and hunters, the steps of traders and genetic material, the wakes of fishing boats, the spoor of livestock, the blood and burdens of warfare.

But, what of the world people grew into, along the way? Can we write about that with fidelity to the embodied experience that generated pots, words, and changes - and exchanges of genetic material-without stories? Archaic DNA and isotope analyses offer us the chance to track a person's physical movement through space, the exciting prospect of using the points of contact between person and the world - through diet, disease, and penetrative sex - to put that elusive blend of phenomenology and materiality into our narratives of pasts without writing. So, the answer to that question must be put very honestly. If we say "yes" but write without stories, then we write meta-history because we write history on top of traces of others' experience. If we can demonstrate their story telling in the pots, in bundles of words, in patterns of mutated and transferred genetic material, in braids of isotopic ratios, then we write with others' experience.

Here are some examples of portals to those stories:

Fleisher and Wynne-Jones tell us about a scatter of thousands of quartz stones near a fourteenth- or fifteenth-century gravestone at Songo Mnara. They then share with us 


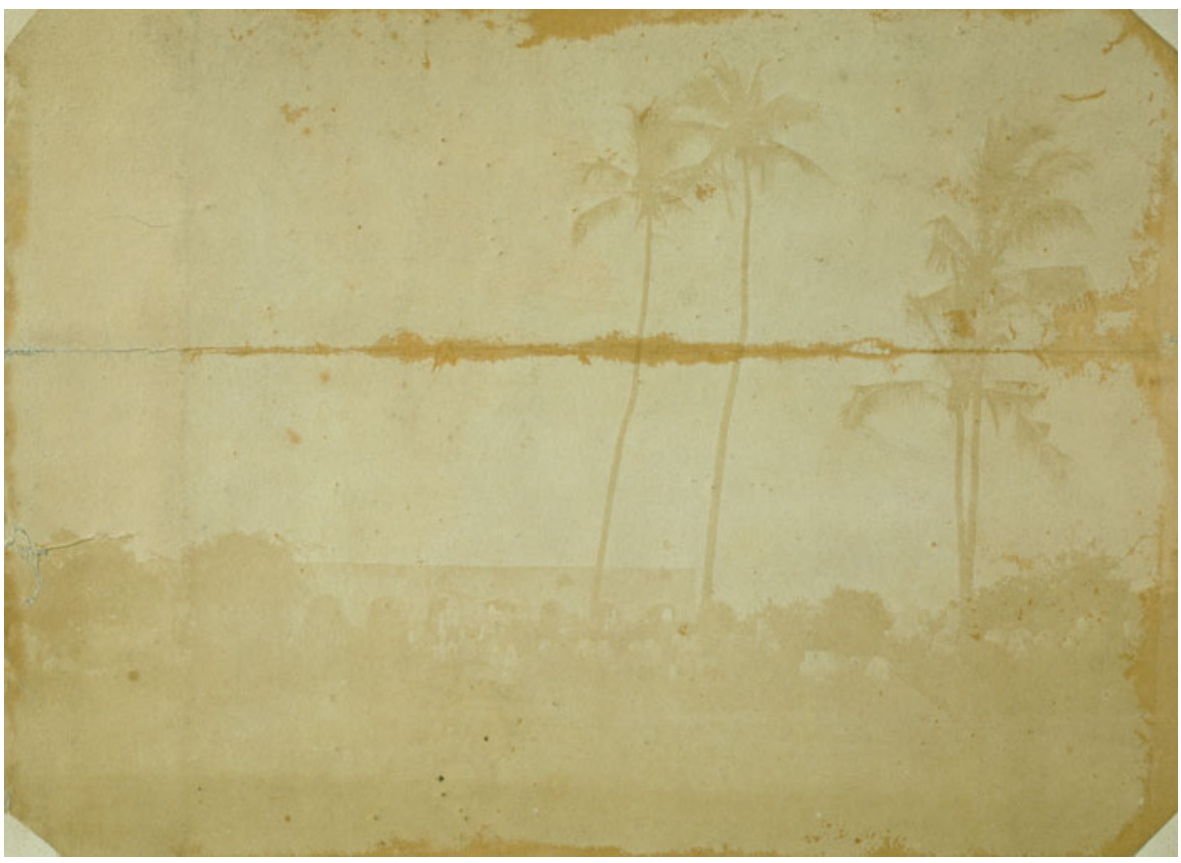

Fig. 1 Burial Ground at Zanzibar, 1860. Photograph by James Augustus Grant. CThe Royal Geographical Society, with IBG

Richard Burton's report of "an ancient custom" about the preparation and placement of similar quartz stones, published in 1872 (See also Plate 1). Burton's story seduces us to imagine fourteenth- or fifteenth-century mourners or rememberers preparing these tokens by cleaning them with water, dressing them with perfume of some sort (a smoke? a liquid?) and letting the strong sun dry them out before sprinkling them —one imagines the thunks and pings as the clutch of five dropped on the dirt or struck one anotherwith words or songs of prayer. Beyond Burton's story, Fleisher and Wynne-Jones' finds of palm phytoliths allow us to imagine their fronds piled, in a heap of green, by the headstone - or flapping in a sea breeze as part of a makuti shade stand protecting the grave - and then, over the next few weeks, turning brittle and brown as the fleeting moments of the funeral turned into the persistent realities of a burial (Fig. 1). Fleisher and Wynne-Jones find the grasses in the central area were kept short, allowing us to imagine the rhythmic swishing of a bent blade, as a gardener worked to keep the grounds around the graves trim and clean. Or the snap of the grass as a cow tore it out and chewed in a blank rhythm. This story evokes lines of movement of many different scales, from the twitching of a nose smelling the perfume, to the sweep of a hand dropping stones, the comings and goings of visitors and mourners, the swings and tears of a grasscutter's work. Then, the moment of another new grave.

McIntosh and Scheinfeldt promise a future in which the overwhelmingly detailed particulars of each of the three billion genomic genealogies can be depicted. Such a picture will possess patterns at many different scales and in many different shapes. Their complexities will mock the clear organic metaphors we draw on today to envision "expansions." Network maps show that powerfully. Blench rightly 
complains about the stiffness of these models, little changed from Guthrie's initial trials. We must turn to metaphor to find relief for this daunting challenge of associating macro, meso, and micro, slow, ambling, and rapid change, and so forth. We wanted the world and, now that its movable shapes draw near, the poverty of our descriptive language looms large.

Organic metaphors hide too much of the contingent and promote too much of the orderly. We need interlacing and overlapping or braided - and broken - lines to think with, instead of combinations of just one straight line, branched or otherwise (Ingold 2007: 118). Interlacing, overlapping, braided images represent the new challenges for thinking with cladistic forms of genetic data, language classifications, and typologies of artifacts, including pots. The crossings of these lines make context stick to them.

Broken lines appear in some of our diagrams, but they usually signal gaps in our knowledge as if the accumulation of information will fill the intervals between the dashes and points. But as the promise of personal detail held out by the study of ancient DNA and isotopic analysis joins the semantic histories imaginable from language evidence, and the intimacies of spatial scale and material practice handed over by archaeologists, these breaks will gain firmer footing in the phenomenological realities of life as lived. Our stories about the past must not snuff out the ways in which our subjects lived lives with breaks of their own - between life stages, gaining and losing names and fortune, between the aspiration for adult children and the creativity of mediumship, and so on. The boundary places that make those "betweens" may be represented by the blank space between dashes and dots, as Darwin did in his tree diagram of the descent of man.

These essays have already given us some powerful examples of ways in which to incorporate context into operational organic metaphors. Fleisher and Wynne-Jones give us an image of the unfolding of a cemetery's life that combines emotion with materiality. de Luna, MacEachern, and McIntosh and Scheinfelt depict the revealingly poor fits between material culture distributions and language territory to embrace the situated character of identity. Blench's image of Bantu-speakers' wayfaring on the high seas of the Atlantic and Indian Oceans requires novel imaginings of the medium of movement. Although students of the Western Indian Ocean have long worked with this image in thinking about the last two millennia there (Nurse and Spear 1985), they have not wondered in Blench's principled manner about the implications for longevity or fragility of network shape in the sequencing of specialized or multi-sited sources of the required expertise. As a result, the maritime dimensions of 'Swahili history' tend to underplay the details of a maritime life.

In the end, my plea is for us to think along lines that lead outside and cross one another more and more. Archaeologists are bringing the shapes of the built, spatial environment of locales, towns, and regions into sharper resolution. Anthropological geneticists promise clearer discernment of patterns of sex and movement. The ethically fraught study of archaic genetic material and stable isotope analysis promises exciting detail on the movement of individual bodies through particular locales, towns, and regions. That leaves the inner worlds of language and embodied experience as the final frontier our narratives claim. I believe that the study of conceptual metaphor offers cognitive processes as a common ground for a portion of our varied empirical evidence. Yet the frayed and contingent qualities of meaning, feeling, and intention that animate that inner world resist the grip of holism. The evidence of 
historical semantics does not submit evenly to the inferential razor of comparative linguistics. If we share the goals of integrity, holism, and integrative explanations of all this evidence, it will be stories that provide that. If we push our descriptive language - in the privacy of our own minds, if not in our scholarly prose - in chancy, new directions our research will head out after new questions and new hypotheses.

Acknowledgments Thanks to Kate de Luna, Jeff Fleisher, Susan McIntosh, and Laura Scheinfeldt for cautions and corrections.

\section{References}

Anthony, D. (2007). The horse, the wheel, and language: How Bronze-Age riders from the Eurasian steppes shaped the modern world. Princeton: Princeton University Press.

Ashley, C. (2010). Toward a socialised archaeology of ceramics in Great Lakes Africa. African Archaeological Review, 27(2), 135-163.

Bayart, J.-F. (1993). The state in Africa: The politics of the belly. Trans: Harper, M., Harrison, C., Harrison, E. London: Longman.

Blench, R. (2012). Two vanished African maritime traditions and a parallel from South America. African Archaeological Review, 29(2/3). doi:10.1007/s10437-012-9115-y.

Bostoen, K., \& Packendorf, B. (2011). Bantu-Khoisan contact in Southwestern Zambia: Gaining deeper insights into sociocultural processes of language contact through interdisciplinary research. Paper presented to the conference Thinking Across the African Past, Rice University, March 11-12, 2011.

Bussmann, H. (1996). Routledge dictionary of language and linguistics. Translated and edited by G. Trauth \& K. Kazzazi. New York: Routledge.

Connerton, P. (2011). The spirit of mourning: History, memory and the body. Cambridge: Cambridge University Press.

David, N., Sterner, J., \& Gavua, K. (1988). Why pots are decorated. Current Anthropology, 29(3), 365-389.

de Luna, K. M. (2012). Surveying the boundaries of historical linguistics and archaeology: Early settlement in South Central Africa. African Archaeological Review, 29. doi:10.1007/s10437-012-9112-1.

Donley-Reid, L. (1982). House power: Swahili space and symbolic markers. In I. Hodder (Ed.), Symbolic and structural archaeology (pp. 63-73). Cambridge: Cambridge University Press.

Donley-Reid, L. (1990). A structuring structure: The Swahili house. In S. Kent (Ed.), Domestic architecture and the use of space: An interdisciplinary cross-cultural study (pp. 114-126). Cambridge: Cambridge University Press.

Ehret, C. (2002). The civilizations of Africa: a history to 1800. Charlottesville: University of Virginia Press.

Ehret, C. (2012). Linguistic archaeology. African Archaeological Review, 29(2/3). doi:10.1007/s10437-0129116-X.

El-Zein, A. H. (1974). The sacred meadows: A structural analysis of religious symbolism in an East African Town. Evanston, IL: Northwestern University Press.

Feierman, S. (2006). Ethnographic regions: Healing, power, and history. In T. J. Luedke \& H. G. West (Eds.), Borders and healers: Brokering therapeutic resources in Southeast Africa (pp. 185-194). Bloomington: Indiana University Press.

Fleisch, A. (2008). The reconstruction of lexical semantics in Bantu. Sprache und Geschichte in Afrika, 19, $67-106$.

Fleisher, J. (2010). Rituals of consumption and the politics of feasting on the Eastern African coast, AD 700-1500. Journal of World Prehistory, 23(4), 195-217.

Fleisher, J., \& Wynne-Jones, S. (2010). Authorisation and the process of power: The view from African archaeology. Journal of World Prehistory, 23, 77-93.

Fleisher, J., \& Wynne-Jones, S. (2012). Finding meaning in ancient Swahili spatial practices. African Archaeological Review, 29(2/3). doi:10.1007/s10437-012-9121-0.

Friedman, J., \& Rowlands, M. J. (1978). Notes toward an epigenetic model of the evolution of 'civilization'. In J. Friedman \& M. J. Rowlands (Eds.), The evolution of social systems (pp. 201-276). London: Duckworth.

Gengenbach, H. (2010). Binding memories: Women as makers and tellers of history in Magude, Mozambique. New York: Columbia University Press. 
Glassman, J. (1995). Feasts and riot: Revelry and rebellion on the Swahili Coast, 1856-1888. Portsmouth: Heinemann.

Glassman, J. (2007). War of words, war of stones: Racial thought and violence in colonial Zanzibar. Bloomington: Indiana University Press.

Horton, M. (1994). Swahili architecture, space and social structure. In M. Parker-Pearson \& C. Richards (Eds.), Architecture and order: Approaches to social space (pp. 132-152). London: Routledge.

Ingold, T. (2007). Lines: a brief history. London: Routledge.

Klieman, K. (2003). 'The Pygmies were our compass': Bantu and Batwa in the history of West Central Africa, early times to c. 1900 C.E. Portsmouth: Heinemann Publishers.

Lakoff, G., \& Johnson, M. (1980). Metaphors we live by. Chicago: University of Chicago Press.

Landau, P. (2010). Popular politics in the history of South Africa, 1400-1948. New York: Cambridge University Press.

Lane, P., Ashley, C., Seitsonen, O., Harvey, P., Mire, S., \& Odede, F. (2007). The transition to farming in Eastern Africa: New faunal and dating evidence from Wadh Lang'o and Usenge, Kenya. Antiquity, 81, 62-81.

MacEachern, S. (2012). The Holocene history of the southern Lake Chad Basin: Archaeological, linguistic and genetic Evidence. African Archaeological Review, 29(2/3). doi:10.1007/s10437-012-9110-3.

MacGaffey, W. (2000). Kongo political culture: On the conceptual challenge of the particular. Bloomington: Indiana University Press.

MacGaffey, W. (2005). Changing representations in Central African history. The Journal of African History, 46(2), 189-207.

McIntosh, R. J. (1998). The peoples of the Middle Niger: Island of gold. Oxford: Blackwell.

McIntosh, R. J. (2005). Ancient Middle Niger: Urbanism and the self-organizing landscape. Cambridge: Cambridge University Press.

McIntosh, S. K., \& Scheinfeldt, L. (2012). It's getting better all the time: Comparative perspectives from Oceania and West Africa on genetic analysis and archaeology. African Archaeological Review, 29(2/3). doi:10.1007/s10437-012-9122-z.

Mitchell, P. (2002). The archaeology of Southern Africa. Cambridge: Cambridge University Press.

Nurse, D., \& Hinnebusch, T. (1993). Swahili and Sabaki: A linguistic history. Berkeley \& Los Angeles: University of California Press.

Nurse, D., \& Spear, T. (1985). The Swahili. Philadelphia: University of Pennsylvania Press.

Ogundiran, A. (2005). Four millennia of cultural history in Nigeria (ca. 2000 B.C.-A.D. 1900): Archaeological perspectives. Journal of World Prehistory, 19(2), 133-168.

Oliver, R. (1966). The problem of the Bantu expansion. The Journal of African History, 7(3), 361-376.

Ortman, S. G. (2011). Using cognitive semantics to relate Mesa Verde archaeology to modern Pueblo languages. In G. S. Cabana \& J. J. Clark (Eds.), Rethinking anthropological perspectives on migration (pp. 111-146). Gainesville: University Press of Florida.

Ortman, S. G. (2012). Winds from the north: Tewa origins and historical anthropology. Salt Lake City: University of Utah Press.

Peterson, D. (1999). Translating the word: Dialogism and debate in two Gikuyu dictionaries. Journal of Religious History, 23(1), 31-50.

Prestholdt, J. (2004). On the global repercussions of East African consumerism. Am Hist Rev, 109(3), 755781.

Reid, A. (2003). Recent research on the archaeology of Buganda. In P. Mitchell, A. Haour, \& J. Hobart (Eds.), Researching Africa's past (pp. 110-117). Oxford: Oxford University School of Archaeology.

Roberts, M. N., \& Roberts, A. F. (Eds.). (1996). Memory: Luba art and the making of history. New York: Museum of African Art.

Robertshaw, P. (2003). The origins of the state in East Africa. In C. Kusimba \& S. B. Kusimba (Eds.), East African archaeology: Foragers, potters, smiths, and traders (pp. 149-166). Philadelphia: University of Pennsylvania Museum of Archaeology and Anthropology.

Robertshaw, P. (2012). African archaeology, multidisciplinary reconstructions of Africa's recent past, and archaeology's role in future collaborative research. African Archaeological Review, 29(2/3). doi:10.1007/s10437-012-9113-0.

Sapir, E. (1916). Time perspective in Aboriginal American culture: A study in method. Department of Mines, Geological Survey Memoir 90, Anthropological Series 13. Ottawa: Government Printing Bureau.

Schatzberg, M. (2001). Political Legitimacy in Middle Africa: Father, family, food. Bloomington: Indiana University Press.

Schoenbrun, D. L. (1997). The historical reconstruction of Great Lakes Bantu cultural vocabulary: Etymologies and distributions. Cologne: Ruediger Koeppe. 
Smail, D. L. (2012). Violence and predation in Late Medieval Mediterranean Europe. Comparative Studies in Society and History, 54(1), 7-34.

Stahl, A. B. (2009). The archaeology of African history. International Journal of African Historical Studies, 42(2), 241-255.

Stephens, R. (2009). Lineage and society in Precolonial Uganda. The Journal of African History, 50(2), $202-221$.

Stokes, A. (1978 [1951]). Smooth and rough. In L. Gowing (Ed.), The critical writings of Adrian Stokes. Volume II, 1937-58 (pp. 213-256). London: Thames \& Hudson.

Sweetser, E. (1990). From etymology to pragmatics: Metaphorical and cultural aspects of semantic structure. Cambridge: Cambridge University Press.

Traugott, E., \& Dasher, R. (2005). Regularity in semantic change. Cambridge: Cambridge University Press.

Ullman, S. (1979). Semantics: an introduction to the science of meaning. New York: Harper \& Row.

Vansina, J. (1990). Paths in the rainforest: Toward a history of political tradition in Equatorial Africa. Madison: University of Wisconsin Press.

Vansina, J. (2004). How societies are born: Governance in West Central Africa before 1600. Charlottesville: University of Virginia Press.

Wittegenstein, L. (2001 [1958]). Philosophical investigations. Trans. by Anscombe, G. E. M., 2nd Ed. Oxford: Blackwell 